\title{
Motivation, Perception and Expectation of Visitors in Heritage Sites, Case: Bunk' Art
}

\author{
Phd Majlinda Muka \\ "Aleksander Moisiu" University, Department of Tourism, Albania \\ elamuka@hotmail.com \\ Phd Necila Cinaj \\ "Aleksander Moisiu" University, Department of Tourism, Albania \\ ncinaj@yahoo.com
}

\section{Doi:10.5901/ajis.2015.v4n3s1p697}

\section{Abstract}

This paper aim to survey the motivation, perception and expectation of visitors in the historical site of Bunk' Art, an atomic bunker built during 1960-1970 in Tirana, Albania turned into a historical museum in November 2014. Exploring visitor's perceptions of the site in relation with historic heritage is an important factor for understanding tourist motivations and behavior for further management of the site. The survey was conducted with tourist visitors directly at the specific site using questionnaires. Data were analyzed using statistical package for social science. Results indicate that identified motives were "educational experience", "heritage experience" and "recreational experience". The visitors considered the site part of their heritage and a good motivation for visiting it in the future.

Keywords: Bunk'Art, motivation, experience, heritage, tourism.

\section{Introduction}

Heritage tourism is considered as a rapidly growing sector of tourism making up a very important component of tourism for many countries. Some researchers define heritage tourism simple as people visiting heritage places or viewing historical resources. Heritage tourism is based on visits by people who want to learn something new or enhance their lives in some ways (Timothy, 2011). Heritage tourism is define as an economic activity that makes use of socio-cultural assets to attract visitors (Fyall at al., 1998), also other researchers suggested that heritage tourism is a phenomenon based on visitors' motivations and perceptions rather than a specific site or attribute (Poria et al., 2001). Based on the importance and perceptions of visitors another definition for heritage tourism is being based on nostalgia for the past and the desire to experience diverse cultural landscapes and forms (Zeppel at al., 1991).

The heritage tourism literature to date has focused on the role of heritage in society, cultural and heritage markets, planning, interpretation, community involvement and issues of authenticity (Alzua at al., 1998). Although is little known about the consumers of heritage. In a survey, Kerstetter at al. (2001) have stated that there is a paucity of research analysing the nature of the relationship between factors such as visitor characteristics, visitor behaviour, motivations and the experiential nature of heritage tourism; as demand for heritage products increase it is required more in depth understanding the characteristics of visitors.

Meanwhile, Hall at al. (1998) have pointed that it is the human dimension that gives rise to heritage resources. In an academic context, there is a need to enhance our understanding of the motivations and thought patterns of tourists (Johnson at al., 1990). In other study, Johnson at al. (1992) have stated that experiential information is important because in order to identify and prioritise important heritage assets for tourism, and to inform cultural development from a demand perspective, there is an essential need to understand the value of historical and cultural resources to tourists in their experience of a destination. In that point of view is quite important to understand visitor characteristics, their motivational factors that influence the performance of the heritage site visits, and for a better management of the site in accordance with the desires and expectations of visitors. Heritage tourism should be understood based on the relationship between individuals and the heritage presented and, more specifically, based on the tourist perception of the site as part of their own heritage (Poria at al., 2001a). 
This paper aims to explore visitor's perceptions of the site in relation with historic heritage as an important factor for understanding tourist motivations and behavior for further management of the site.

\section{Literature Review}

According to the researchers sites hold personal values, beliefs and memories for the visitor. Different authors presents a wide range of reasons for visiting historic heritage sites, so understanding the motivations for a visit is quite important for tourism research. Visits are motivated by a desire to enhance ones on cultural self, to learn something new, to satisfy one's curiosity, or simply to use up excess time. In short, heritage tourism encompasses a multitude of motives, resources and experiences and is different for every individual and every place visited (Timothy, 1997). The most common reasons to visit a heritage site reported in the literature are education (i.e. the tourists' willingness to learn) and entertainment (i.e. the tourists' desire to be entertained). But other reasons, linked to the attributes of the artefacts presented related to someone's heritage may also play a part. Poria at al., (2006) have stated that the desire of tourists to be exposed to their own heritage and thus to be involved in a personal 'heritage experience' is another good reason. According to the researchers in environmental psychology, Scott at al., (1997) explained that the relationship between individuals and environment is related to one's experience. In heritage tourism literature is argued that the tourists' perceptions of a site and their activities relative to it are important for understanding of their behaviour (Poria et al., 2001a).

\section{Research Method}

The specific site chosen for the focus of the study is the Bunk'Art, a secret underground bunker built decades ago to survive a possible nuclear attack by the Soviet Union or the United States, the attack that never came. The bunker with 5 security doors, named in the years of the communist regime as "Object 0774", is five floors below ground and has over 106 rooms. The bunker is designed and set up to accommodate all the command line of the government in case of a potential chemical bombing or atomic attack to the Albanian capital: this is confirmed by the presence of a big number of rooms, some of which are designated as emergency apartment for the dictator Enver Hoxha, the Prime Minister and at the same time for all the political and military nomenclature of the country.

Everything is kept secret for 36 years after the official inauguration was done on 24 June 1978. The idea to build this bunker is borrowed from the military of the time during the communist dictatorship after a visit conducted in North Korea. The structure was built between 1972 and 1978, it's consists of 106 rooms distributed into five levels, including also an assembly-auditorium hall with total area of 2685 square metres.

In all rooms of the museum are exhibited weapons, uniforms, documents, various maps and other details serving at the time, video installations, images, objects and digital equipment to recreate a historical journey of emotional content which represents the case of a reflection and recognition of national history even for the youngest.

The museum's objective is to commemorate the main historical events in the period between 1939 and 1944 with passages of the before Italian invasion and after Nation Liberation. The messages are transmitted within symbolize the isolation of communist Albania, but also the constant confrontations between the Communist bloc and the West bloc during the Cold War. On November 2014, the "Bunk'Art" opened its doors as a museum. The museum is now considered one of heritage sites in Tirana and more than 60,000 people visited the site until January 2015.

Understanding specific tourist motivations can help planning better products and services and more efficient marketing communication. To explore visitor's perceptions of the site in relation with historic heritage as an important factor for understanding tourist motivations and behaviour for further management of the site, a research survey through structured questionnaires was conducted.

87 randomised visitors were included to the research study during 27-29 November 2014, the respondents were given questionnaires in person and the papers were filled on site. The sample comprised both domestic and international visitors (tourists) above the age of 15. Questionnaire was designed in Albanian and English language. There were a set of questions to evaluate visitor perception in relation to the site as heritage one, questions to measure the visitors' overall motivation and to find out visitors experiences (based on literature). Socio demographic information and home country data of the respondents were gathered. Questions used aimed to identified different motives for their visit giving different suggestions with a scale from 1 to 5 (based on Likert Scale) to answer and one open space answer for respondent's own proposal. 


\section{Analysis}

In the survey were included 87 participants (visitors), (58.3\% female and $41.7 \%$ male). Of the sample $36.8 \%$ were graduated, $8.4 \%$ were post graduated and $54.7 \%$ had high school education. Dominant visitor age was $20-30$ years old or (44\%), and about $89 \%$ were of Albanian nationality. All the participants had never visit before the Bunk'Art museum.

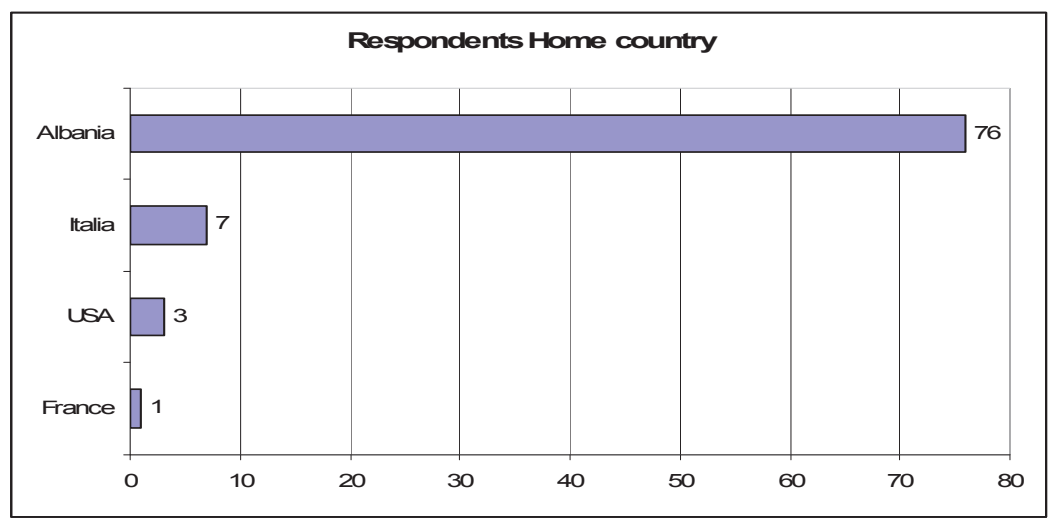

Figure 1. Respondents' home country

The reason of very few foreign visitors obviously is related to the fact that the museum has recently open and were the earliest days of visit after the inauguration. The fact that a military object was transformed into a national historical museum means closer connection with the domestic visitors.

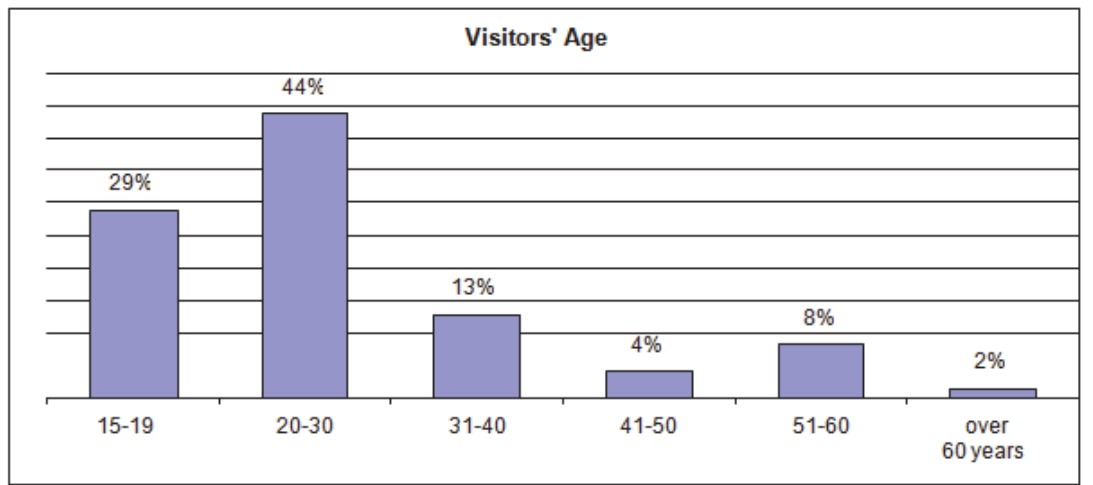

Figure 2. Visitors' Age

The presence of young visitors, dominant age were 20-30 years (44\%) and 15-19 years (29\%), argued the fact that tendency to learn details of the history of a period which has left traces in overall development of socio-economic conditions and political ones of the country is significantly expressed in these ages, associated with shocking existence of such an object. We noticed a new approach to the integration of new age to visits heritage buildings as an expression of the demand for heritage tourism. The limited number of the respondents may affect the results of the study.

According to the source information, the majority of visitors got information for the museum from media $52 \%$, from friend and relatives $36,9 \%$ from advertisement $7,2 \%$ and very few got information from travel agency only $2 \%$ of the respondents. 


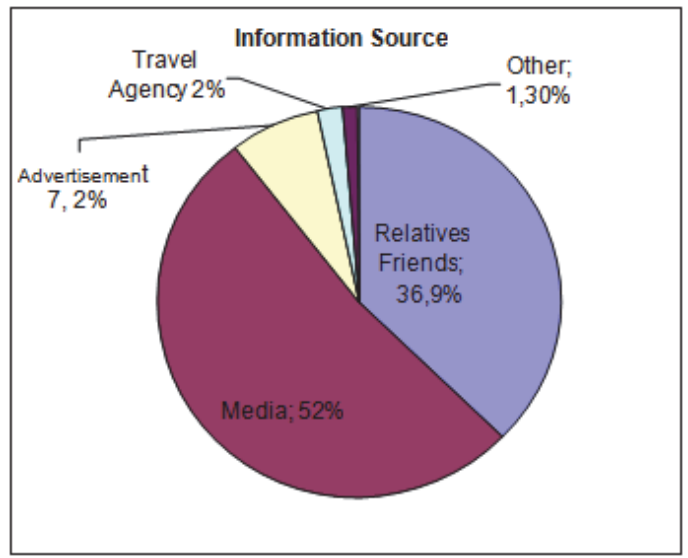

Figure 3. Information Source

First question used in questionnaire aimed to understand visitor perceptions in relation to own heritage and to identify reasons for the visit. Respondents should answer based on Likert scale where 1 indicated "Strongly Disagree" and 5"Strongly agree". Based on the mean score of respondents (Table 2) Bunk Art museum is considered a heritage site that generates own emotions related to historic identity.

To determine the reliability of scale (as it was chosen multiple Likert scale answers in the survey) the Cronbach's Alpha is used to measure the internal consistency. As it seen from the data in table1, the value of Cronbach's Alpha is 0.902 , which indicates a high level of internal consistency, so the questions used measure the same latent variable.

Table 1. Visitors site perception

\begin{tabular}{|c|cc|cc|c|c|}
\hline & \multicolumn{2}{|c|}{$\begin{array}{c}\text { The site represent something which } \\
\text { relates to your identity } \\
\text { Frequency }\end{array}$} & \multicolumn{2}{|c|}{$\begin{array}{c}\text { The site generates a sense of } \\
\text { belonging for you }\end{array}$} & \multicolumn{2}{c|}{$\begin{array}{c}\text { Bunk Art represent part of your } \\
\text { personal heritage }\end{array}$} \\
Percent & Frequency & Percent & Frequency \\
\hline Valid Strongly Disagree & 7 & 8 & 3 & 3.4 & 5 & 5.7 \\
2 & 22 & 25.3 & 10 & 11.5 & 13 & 14.9 \\
3 & 30 & 34.5 & 39 & 44.8 & 25 & 28.7 \\
4 & 18 & 20.7 & 23 & 26.4 & 29 & 33.3 \\
Strongly Agree & 10 & 11.5 & 12 & 13.8 & 15 & 17.2 \\
\hline
\end{tabular}

Reliability Statistics

\begin{tabular}{|c|c|c|}
\hline Cronbach's Alpha & $\begin{array}{c}\text { Cronbach's Alpha Based } \\
\text { on Standardized Items }\end{array}$ & N of Items \\
\hline .902 & .908 & 3 \\
\hline
\end{tabular}

Table 2 Item Statistics

\begin{tabular}{|l|c|c|c|}
\hline & Mean & Std. Deviation & N \\
\hline The site represent something which relates to your identity & 3.02 & 1.120 & 87 \\
The site generates a sense of belonging for you & 3.39 & .907 & 87 \\
Bunk Art represent part of your personal heritage & 3.41 & 1.116 & 87 \\
\hline
\end{tabular}

Motivation of the visit are different to individuals and differ regarding to site perceptions of individuals. Respondents have chosen as visit motivations: to learn about the history of Albania, should visit the site, for its historical background, it's important to visit the site, want to learn about WWII, the site is part of own heritage, feel emotionally involved, it's a new tourist attraction. Entertainment as a motivation has loaded lower mean scores; the visitors have also chosen to have a 
day out, to entertain or to relax. As it seen educational element occupies important place among the motivations of the visit, serving as the most important reason for the site visits in which is represented a considerable part of history of the country.

Test reliability of variables, Cronbach's Alpha is 0.924 which confirm strong correlation between variables.

Table 3. Visitor Motivations

\begin{tabular}{|c|c|c|c|}
\hline & $\mathrm{N}$ & Mean & Std. Deviation \\
\hline You want to learn about history of Albania & 87 & 3.93 & .643 \\
\hline You feel that you should visit the site & 87 & 3.90 & .890 \\
\hline You think is important to visit the site & 87 & 3.86 & 1.014 \\
\hline You want to learn about site's background & 87 & 3.82 & 1.105 \\
\hline You decided to visit because of its historical background & 87 & 3.78 & .908 \\
\hline You want to learn about WWII & 87 & 3.43 & 1.148 \\
\hline You visit Bunk Art because it's part of your own heritage & 87 & 3.36 & 1.120 \\
\hline You feel emotionally involved & 87 & 3.26 & 1.401 \\
\hline You want to entertain & 87 & 3.24 & 1.355 \\
\hline You decided to visit because is a new tourist attraction & 87 & 3.15 & 1.498 \\
\hline You want to relax & 87 & 3.09 & 1.030 \\
\hline You have decided to visit museum because feel a sense of belonging to the site & 87 & 3.09 & 1.063 \\
\hline You want to have a day out & 87 & 3.00 & 1.191 \\
\hline
\end{tabular}

Reliability Statistics

\begin{tabular}{|c|c|c|}
\hline Cronbach's Alpha & Cronbach's Alpha Based on Standardized Items & N of Items \\
\hline .924 & .933 & 13 \\
\hline
\end{tabular}

For better understanding and to explain the correlation between variables used, a Factor Analysis is undertaken. Factor Analysis attempts to bring interrelated variables together under more general, underlying variables. The determination about number factors is made according Eigenvalue larger than one (Guttman-Kaiser rule), the Principal Component Analysis is applied using oblique rotation. To determine variables included in each factor were included those above 0.4 (which explain around $16 \%$ of variance) (Field, 2000). Three factors were identified explaining $66.4 \%$ of variance. (The first factor $52.1 \%$, second one $7.9 \%$ and third factor $6.4 \%$ ).

Table 4. Factor Analysis for Motivation

\begin{tabular}{|l|c|c|c|}
\hline & \multicolumn{3}{|c|}{ Component } \\
\cline { 2 - 4 } & 1 & 2 & 3 \\
\hline You want to learn about history of WW II & 0.896 & & \\
you decided to visit because want to learn to its historical background & 0.710 & & \\
feel that you should visit the site & 0.708 & \\
You want to learn about history of Albania & 0.647 & \\
feel emotionally involved & & 0.939 & \\
it's part of your heritage & & 0.930 & \\
feel a sense of belonging to the site & & 0.808 & \\
because of its historical background & & 0.759 & \\
it's a new tourist attraction & & & 0.917 \\
want to have a day out & & & 0.831 \\
want to entertain & & & 0.813 \\
want to relax & & & -0.690 \\
\hline
\end{tabular}

Extraction Method: Principal Component Analysis.

Rotation Method: Oblimin with Kaiser Normalization

Rotation Converged in 5 Iteration

Based on Principal Component Analysis (PCA), three main correlated factors were identified, named Educational Factor -the first, Heritage Factor the second and Entertainment Factor- third. Factor identified gives the possibility for further 
investigation between variables. As indicated by the analysis of factors an important element underlying motivation for the visit is connected to learn the history of Albania and especially the site's background history and what it represented by the time. Another underlined factor motivation for visit was experience of Heritage, considering the site part of the historical heritage emotional feeling involved in connection with. Part of visitors considered the site as a new tourist attraction with historical value and as such constitutes a leisure motive for the visit, while none of the visitors did not considered an important motivation relax, so the main focus remain in the importance of educational experience and heritage ones.

Respondents were asked to evaluate their overall motivation to visit Bunk'Art in a scale, divided in three sections: poor motivated, relatively motivated and highly motivated. Correlation between socio-demographic data and visitor's site perception were examined. Although appeared statistically significant $(p<0.05)$ in One Way Anova Test, relationship between visitor's site perception and level of education appear with light differences between groups. So, those respondents whose got post graduate and graduated education perceive more the site as being part of their heritage compare to high school group.

Table 5. correlation between socio-demographic variable (Education) and site perception variable: Bunk Art represent part of your personal heritage

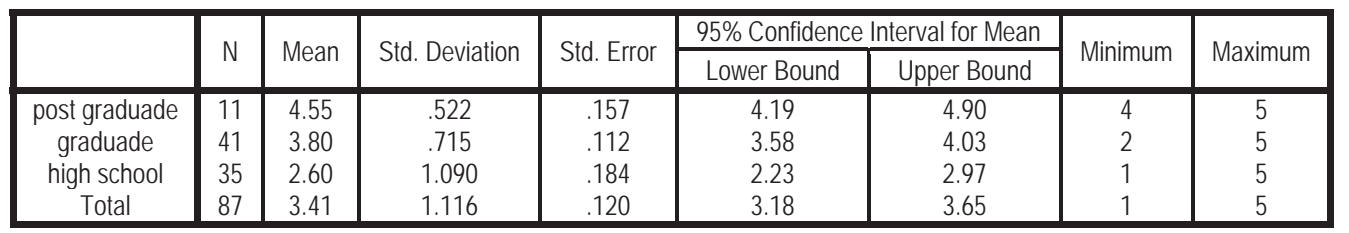

Table 6. Statistic correlation

Dependent Variable: Bunk Art represent part of your personal heritage Tukey HSD

\begin{tabular}{|cc|c|c|c|c|c|}
\hline \multirow{2}{*}{$(\mathrm{I})$ Education } & \multirow{2}{*}{ (J) Education } & \multirow{2}{*}{ Mean Difference $(\mathrm{I}-\mathrm{J})$} & \multirow{2}{*}{ Std. Error } & \multirow{2}{*}{ Sig. } & \multicolumn{2}{|c|}{$95 \%$ Confidence Interval } \\
\cline { 5 - 7 } & & & & Lower Bound & Upper Bound \\
\hline \multirow{2}{*}{ post graduade } & graduade & $.741^{*}$ & .295 & .037 & .04 & 1.45 \\
& high school & $1.945^{*}$ & .301 & .000 & 1.23 & 2.66 \\
\multirow{2}{*}{ graduade } & post graduade & $-.741^{*}$ & .295 & .037 & -1.45 & -.04 \\
& high school & $1.205^{*}$ & .200 & .000 & .73 & 1.68 \\
high school & post graduade & $-1.945^{*}$ & .301 & .000 & -2.66 & -1.23 \\
& graduade & $-1.205^{*}$ & .200 & .000 & -1.68 & -.73 \\
\hline
\end{tabular}

*The mean difference is significant at the 0.05 level.

Strong correlation is seen between Education level and Heritage Factor (Pearson' $r=0.745, p=0.000$ ) significant at 0.01 level (2-tailed). The results indicated moderate relationship between Education level and Educational Factor (Pearson' $r=0.587, p=0.000)$ significant at 0.01 level (2-tailed) and weak correlation between Education level and Entertainment Factor is seen (Pearson' $r=-0.267, p=0.013$ ) significant at 0.05 level (2-tailed).

Relationship between motivation factors identified and overall visit motivation is verified. Relationship between Educational Factor and overall motivation is statistically significant, (Pearson' $r=0.288, p=0.004$ ) correlation is significant at 0.05 level (2-tailed).The main reason for the visit to the site reflected by visitors is associated with educational behavior, learning about history (the site historical background, history of Albania as well as the history of the WWII and Albanian role during it). Statistically significant correlation is verify between overall motivation and Heritage Factor, (Pearson' $r=0.329, p=0.002$ ), what it proves that beside educational elements another basic motivation for the site visits is considered its historical heritage. There was no statistically significant relationship observed between overall motivation and Entertainment Factor, despite the fact that the leisure pursuit were identified as reasons for carrying out the visit.

The followed up questions used in questionnaire aimed to evaluate the visit experience among visitors after performing the visit on the site. The mean scores of visitors experience are shown in table 7. A five level Likert Scale was used to measure their answers, where 1 indicated "Strongly Disagree" and 5"Strongly Agree". Test statistics for 
reliability shows value of Cronbach's Alpha 0.542 , which means good correlation between variables.

Table 7. Experience from the visit

\begin{tabular}{|c|c|c|c|}
\hline & Mean & Std. Deviation & $\mathrm{N}$ \\
\hline Your visit in the site allow you to learn something new & 3.90 & .716 & 87 \\
\hline Provided with information about history of Albania & 3.84 & .400 & 87 \\
\hline Provided you with historical information about role of Albania during WWII and after & 3.85 & .390 & 87 \\
\hline Make you feel emotionally involved & 3.45 & .985 & 87 \\
\hline Strengthen the link between you and your history & 3.59 & .947 & 87 \\
\hline Make you feel connected to your heritage & 3.18 & .771 & 87 \\
\hline Your visit entertained you & 2.89 & 1.016 & 87 \\
\hline Create possibility to knew new persons & 2.74 & .769 & 87 \\
\hline
\end{tabular}

Reliability Statistics

\begin{tabular}{|c|c|c|}
\hline Cronbach's Alpha & Cronbach's Alpha Based on Standardized Items & N of Items \\
\hline .542 & .547 & 8 \\
\hline
\end{tabular}

Data from Table 7 shows that visitors provided historical information about role of Albania during WWII and after, enhanced the link between history and their knowledge. After visit performed they felt emotionally involved and connected to the site heritage. In the meantime, visit performed included them in an entertainment activity giving the possibility to be introduced to a new touristic attraction as well as to know different people. So people included in visiting heritage site seeks other experiences rather than learning/educational and heritage experiences.

A Factor Analysis technique was performed to understand better the correlation between variables under a common underlying variable. The determination about number of factors is made according Eigenvalue larger than one (Guttman-Kaiser rule), the Principal Component Analysis is applied using promax rotation. To determine variables included in each factor were included those above 0.4. As it shown in table 7, three main factors were determinate explaining $54.2 \%$ of variance. Eigenvalue: first factor (2.198), second factor (1.088) and the third factor (1.078).

Table 7. Factor Analysis for tourists experience on site

\begin{tabular}{|l|c|c|c|}
\hline & \multicolumn{2}{|c|}{ Component } \\
\cline { 2 - 4 } & 1 & 2 & 3 \\
\hline Make you feel connected to your heritage & .822 & & \\
Make you feel emotionally involved & .726 & & .490 \\
Strengthen the link between you and your history & .401 & .690 \\
Provided you with historical information about role of Albania during WWII and after & & .690 \\
Provided with information about history of Albania & & .555 & .536 \\
Your visit entertained you & & \\
Your visit create possibility to knew new persons & .466 & -.413 & -.475 \\
Your visit in the site allow you to learn something new & .466 \\
\hline
\end{tabular}

Extraction Method: Principal Component Analysis.

Rotation Method: Promax with Kaiser Normalization.

Rotation converged in 6 iterations.

The first factor named "Emotional experience" is different from second factor named "Learning experience". The Emotional Experience Factor summarizes emotional feeling connected to heritage while visiting the site. Meanwhile the strengthen link between visitors and history variable, is listed between "Emotional Experience" and "Learning Experience", because the visitors have experienced both of feeling, they enriched the historic information owned and the same time felt connected emotionally to this heritage site. The second factor includes "Learning experience" gained in the frame of historical information learning that happened during the performed visit. As well as the visitors have learn something new during the visit variable, is listed in positive way in "Emotional Experience" factor and in negative way in "Learning experience"-second factor and in the same way in third factor too. What does it mean is that visitors during performing visit have experienced at the same time not only emotional experience related to the site, but learning 
information process has happened, they enriched historical information through entire environment exposed, and doing so they have proved entertainment experience -third Factor. Also, knowing new persons is an associated fact and an entertainment experience too.

Table 8. Site perception correlations to Learning experience

\begin{tabular}{|ll|c|c|}
\hline & & Your perception regarding the site & Learning Experience \\
\hline \multirow{4}{*}{ Your perception regarding the site } & Pearson Correlation & 1 & $.238^{*}$ \\
& Sig. (2-tailed) & & .026 \\
& $\mathrm{~N}$ & 87 & 87 \\
& Pearson Correlation & $.238^{*}$ & 1 \\
Learning Experience & Sig. (2-tailed) & .026 & \\
& $\mathrm{~N}$ & 87 & 87 \\
\hline
\end{tabular}

${ }^{*}$ Correlation is significant at the 0.05 level (2-tailed).

Statistically significant correlation is seen between site perception and 'Learning "experience, (Pearson' $r=0.238, p<0.05$ ). The more visitors considered the site part of own heritage the more willingness they express in learning experience.

Table 9. Site perception Correlations to Emotional Experience

\begin{tabular}{|ll|c|c|}
\hline & & Site perceptions & Emotional experience \\
\hline \multirow{3}{*}{ Site perceptions } & Pearson Correlation & 1 & $.645^{* *}$ \\
& Sig. (2-tailed) & & .000 \\
& $N$ & 87 & 87 \\
\multirow{3}{*}{ Emotional experience } & Pearson Correlation & $.645^{* *}$ & 1 \\
& Sig. (2-tailed) & .000 & \\
& $\mathrm{~N}$ & 87 & 87 \\
\hline \multirow{2}{*}{ Correlation is significant at the 0.01 level (2-tailed). }
\end{tabular}

Strong correlation is seen between site perceptions and "Emotional" experience (Pearson' $r=0.645, p=0.000$ ). Visitors have perception of site as being part of their history, they involved in emotional experience during the site visit.

\section{Results}

The "past" represented to Bunk Art museum motivated visitors in different aspects. Three main reasons were identified during the survey that leads visitors /tourists to visit the site: Educational factor, Heritage and Recreational factors. Each one of them presents differentiation regarding the motives involved based on individual perceptions of visitors in relation to the site.

Heritage experience as a motivation factor identified includes the reasons for visit related to the perception of the site as own heritage.

Reasons included to the Educational factor were related to learning motivations; meanwhile the third group encompasses reasons not related to the first two groups. At its base lie Entertainment motives.

By socio-demographic factors, education level has a direct connection with the perception of the site. The higher the education level the stronger the perception of the site as part of heritage $(p<0: 05)$. Also is noticed statistically significant correlation between education level and the identified factors Educational and Recreational, although the relationship to Recreational experience factor is weak and negative.

This is the first attempt to make visitors segmentation based in their perception of the site. Based on the motivation and experiences factors identified it is argued that individuals differs and have different experiences and expectations performing the visit.

The undertaken study present an opportunity to have a better understanding of the motivations for visits at the heritage site as well as the experiences gained offers a better line for marketing and site management.

The number of respondents was 87 persons, as such it may affect the results of the study, so the findings of the 
survey can be seen as rather guiding than generalized. The survey was the first one to be implemented to Bunk'Art museum as such there is no other study to compare the results with. Further research may explore the relationship between site perception factors and expectation from visit among visitors for better understanding and managing the heritage site and to better satisfy visitor desires.

Suggestions provided by the visitors with the aim of improving performance, converge on the necessity of interpretive guides accompanying during the site visit as a very important and stimulant factor of emotions involvement to feel more connected to the heritage site.

The findings of this survey can serve as a resource guide for decision-making institutions that are responsible for the management of site.

\section{References}

Alzua, A., O'Leary, J., A. Morrison (1998). Cultural and Heritage Tourism: Identifying Niches for International Travelers. The Journal of Travel and Tourism Studies, 9 (2), 2-13.

Field, A., (2000).Discovering statistics using SPSS for windows. London. SAGE publications.

Fyall, A., Garrod, B (1998). Heritage tourism: At what price? Managing Leisure 3 (4), 213-228.

Hall, C. M., McArthur, S (1998). Integrated heritage management: Principles and practice. London: The Stationary Office.

Johnson, P., Thomas, B (1990). Measuring local employment impact of tourist attractions. Regional Studies, 24, (5) 395-403

Johnson, P., Thomas, B (1992). Choice and demand in tourism. London. Mansell Publishing Limited.

Kerstetter, D.L., Confer, J.J., and A.R. Graefe (2001). An exploration of the specialization concept within the context of heritage tourism. Journal of Travel Research, 39(3), 267-274.

Poria, Y (2001). Challenging the present approach to heritage tourism: Is tourism to heritage places heritage tourism? Tourism Review, $56(1 / 2), 51-53$.

Poria, Y., Butler, R., Airey, D (2001a). Clarifying heritage tourism : a comment. Annals of Tourism Research, 28 (4), 1047-1049.

Poria, Y., Reichel, A., Biran, A ( 2006). Heritage site management - Motivations and Expectations. Annals of Tourism Research, 33(1), 162-178.

Scott, M.J., D.V. Canter, D.V (1997). Picture or place? A multiple sorting study of landscape. Journal of Environmental Psychology, 17, 263-281.

Timothy, D. J (1997). Tourism and the personal heritage experience. Annals of Tourism Research, 24 (3), 751-754.

Timothy, D J (2011). Cultural Heritage and Tourism. Channel View Publication.

Zeppel, H., C.M. Hall (1992). Arts and heritage tourism. Special Interest Tourism, London. Belhaven Press. 